\title{
An efficient protocol for mass multiplication of Centella asiatica (L.) Urban and determination of its phenolic content
}

\author{
Shweta Kumari, Maheshwar Prasad Trivedi* \\ Department of Botany, Patna University, Patna- 800005 , Bihar, India
}

Received: August 18, 2020 Revised: December 23, 2020 Accepted: December 26, 2020 Published: December 30, 2020

*Corresponding Author: Maheshwar Prasad Trivedi, E-mail:mptrivedi1956@ rediffmail.com

\begin{abstract}
The present study was focused on standardizing a protocol for callus induction as well as regeneration in Centella asiatica from leaf and stem as explants. Stem and leaf explants have been inoculated in $\mathrm{B}_{5}$ media supplemented with BAP $(0.1-2.5 \mathrm{mg} / \mathrm{l}), \mathrm{kn}(01-04 \mathrm{mg} / \mathrm{l})$ and NAA $(0.1-0.5 \mathrm{mg} / \mathrm{l}), 2,4-\mathrm{D}(0.2 \mathrm{mg} / \mathrm{l})$ for callus induction. The combination of BAP and NAA leads to the formation of green, brown, compact and friable calli while Kn and 2, 4-D induced brown calli. Highest shooting was obtained from BAP $(1.5 \mathrm{mg} / 1)$ and NAA $(0.5 \mathrm{mg} / 1)$. When the shoots were inoculated in half strength of $\mathrm{B} 5$ media fortified with $0.1 \mathrm{mg} / \mathrm{l} \mathrm{BAP}$ and $0.5 \mathrm{mg} / \mathrm{l} \mathrm{NAA}$ showed cent percent rooting with the highest number of roots per shoot $(11.05 \mathrm{~cm})$ and maximum root length $(1.86 \mathrm{~cm})$. Stem showed the best explants for callus induction as compared to leaf explants. A low concentration of plant growth regulators was unable to induced callus response in leaf and stem explants. Phenolic content analysis showed that calluses contain more amounts of phenol $(0.81 \mathrm{mg} / \mathrm{gmdw})$ as compared to both leaf $(0.63 \mathrm{mg} / \mathrm{gmdw})$ and stem $(0.59 \mathrm{mg} / \mathrm{gmdw})$ explants.
\end{abstract}

KEYWORDS: Centella asiatica, In vitro propagation, Phenol content

\section{INTRODUCTION}

Plants are natural source of medicine and used in curing diseases. The medicinal plants have been used as the herbal remedies. At present use of natural products in treating diseases are increasing. Herbal drugs have achieved much popularity due to increasing awareness towards personal health which leads to maintained health through the natural products [1]. The high public demands of these medicinal plants required its conservationthrough the micropropagation as well as enhancement of secondary metabolites through the callus culture, suspension cultures and treatment of elicitor's molecule [2]. Centella asiaticawhich is also known as Indian pennywort are small herbaceous annual plant widely distributed in India, Malaysia, SriLanka, Indonesia, and other parts of Asia $[3,4]$. The plant belongs to the family Apiaceae [5]. The extract of Centella asiaticais used for wound healing [6] as well as various skin diseases viz: leprosy, lupus, varicose ulcer,eczema, psoriasis and female genital urinary tract infections [7]. Ethanolic extract of Centella has been well elucidated for antibacterial activity [10]. Apart from antibacterial activity, essential oil of C. asiatica is endowed with antimicrobial activity $[9,11]$.Crude methanolic extract as well as hydroalchoholic activity showed antioxidant properties [8]. Centella asiaticais assumed to be effective on the connective tissues by strengthened weakened viens[12]. Triterpene of C.asiatica also showed antidepressant activity [13].Centella asiatica of Asiatic region enhances GABA in cerebral cortex which depicts its conventional anxiolytic and anticonvusalant property $[7,14]$. The major constituents of these medicinal plants are madecassid acid, asiatic acid, centellasaponins as well as three types of asiaticoside viz: asiaticoside, asiaticoside A and asiaticoside B [15]. Because of great demands of these bioactive molecules, researchers focused to develop plant tissue culture techniques to increase the number of plantlets as well as to enhance the secondary metabolite production through the callus culture [16, 28]. Therefore, the major thrust of present investigation was to standardize a protocol for micropropagation of this valuable medicinal plant in $\mathrm{B} 5$ media. We also determined bioactive molecules productioninvivo and invitrocondition.

\section{MATERIAL AND METHODS}

\section{Source of Explant and Surface Sterilization}

Germplasmsof Centella asiatica were collected from different ecological niches of Bihar such as Betiah, Purnia, Motihari

Copyright: (C) The authors. This article is open access and licensed under the terms of the Creative Commons Attribution License (http://creativecommons.org/licenses/by/4.0/) which permits unrestricted, use, distribution and reproduction in any medium, or format for any purpose, even commercially provided the work is properly cited. Attribution — You must give appropriate credit, provide a link to the license, and indicate if changes were made. 
and Patna, planted in garden of PG Department of Botany, Patna University Patna. One year grown plants were selected as explants for micropropagation on the basis of their morphological features and vigorous growth. The germplasm of Motihari showed maximum growth in leaf as well as size of leaf and stem as compared to other districts of Bihar. Therefore, thegermplasm of Motihari District of Bihar for the Micropropagation of Centella asiatica. Stem and leaf were cut from the mother plantand washed under the running tap water for 30 minutes. Afterthen washed explants were soaked in $5 \%(\mathrm{v} / \mathrm{v})$ teepol for $8 \mathrm{~min}$ and washed properly with double distilled water, followed by surface sterilization by $0.1 \%(\mathrm{w} / \mathrm{v})$ freshly prepared mercuric chloride for 5 minute and repeated washing 3-4 times with sterile double distilled water under laminar airhood. Explants were cut in $2-2.5 \mathrm{~cm}$ in small pieces.

\section{Inoculation of Explants in B5 Media}

The surface sterilized explants were dried out on autoclaved filter paper and further inoculated in plant tissue culture tubes $(150 \times 25 \mathrm{~mm})$ under laminar air hood containing $20-25 \mathrm{ml}$ of B5 media[17] augmented with different combination and composition of auxins such as 2, 4-D, NAA and cytokinins BAP and kinetin. $\mathrm{pH}$ of media was adjusted with the help of $\mathrm{NaOH}$ and $\mathrm{HCl}$ prior to autoclave at $1.05 \mathrm{~kg} / \mathrm{cm}^{2}$ pressure and $121{ }^{\circ} \mathrm{C}$ temperature for $15 \mathrm{~min}$. The uniform culture condition was maintained in plant tissue culture laboratory of department at temperature $25 \pm 2{ }^{\circ} \mathrm{C}$ under a photoperiod of $16 / 8 \mathrm{hr}$ with relative humidity (RH) 60-70\% and light intensity of 35-40 $\mathrm{molm}^{-2} \mathrm{~S}^{-1}$ (white fluroscent light). Twenty replicates raised per treatment were repeated three times. Values represent means $\pm \mathrm{SE}$ of 10 explants per culture vessels. The cultures were maintained by subculturing at regular interval of 4 weeks. Data were collected after inoculation of 4 week. Randomly selected in vitro grown calluses were further transferred in freshly prepared shooting B5 media supplemented with BAP and NAA for proliferation of callus into shoots. The number of shoots per callus and length of shoots were recorded after 4 week. When the shoots achieved the length of $2-2.5 \mathrm{~cm}$, they were further transferred in rooting media fortified with BAP and NAA in tissue culture jar (PW1300, Himedia). Data were collected after 4 week of inoculation in shooting and rooting media. Percentage of shooting, number of roots and length of root (in $\mathrm{cm}$ ) were also recorded.Moisture contents of randomly selected calluses were determined by the drying it in incubator at $30{ }^{\circ} \mathrm{C}$. Firstly we measured the weight of fresh calluses then kept the material in Petri plates and placed it in incubator for 72 hours. The moisture of calluses wasdetermined using the formula, $\%$ of moisture content $=($ FC- P $)-($ FD-P $) \times 100 /($ FC- $P)$, where, $\mathrm{P}$ is weight of empty Petri plates, FC is weight of Petri plates with fresh calluses and FD is weight of Petri plates with dry calluses.

The total phenolic content of Invitro grown callus and In vivo explants was studied by the method of Govarthanan etal. with slightly modification [4]. The folin-ciocalteu's (FC) reagent was used fordetermination of total phenolic. One $\mathrm{ml}$ of methanolic extract and nine $\mathrm{ml}$ of double distilled water was added in $25 \mathrm{ml}$ of conical flask. One $\mathrm{ml}$ of folin - ciocalteu reagent was added in the mixture with constant stirring. After $5 \mathrm{~min} 10 \mathrm{ml}$ of $7 \%\left(\mathrm{Na}_{2} \mathrm{CO}_{3}\right)$ was added in the mixture and volume was made up to $25 \mathrm{ml}$ with sterile distilled water. The reaction was incubated for $90 \mathrm{~min}$ on room temperature and absorbance was determined at $550 \mathrm{~nm}$ with the help of an ultraviolet (UV) visible spectrophotometer. Total phenolics content was expressed as mg gallic acid equivalents (GAE)/gm of C. asiatica extract. Meanwhile after induction of roots plantlets were removed from the media and cleaned with double distilled luke warm water for removal of agar and transferred into sterile plastic pots containing sand, soil, vermiculatie (1:1:1) covered with sterile polythene bags. In order to acclimatize plants into field, after 2 week polythene bags were opened and transferred in earthen pots filled with 3:1 mixture of soil and vermicompost. Invitro grown plantlets were maintained in green house in normal day-night condition.

\section{Statistical Analysis}

A complete random block designed was design for all investigations such as callus culture, shoot induction, rooting and plant regeneration. Data were calculated on the basis of number of explants used. Twent replicates per treatment were repeated three times and values represented by mean $\pm \mathrm{SE}$ ten explants per culture vessels.

\section{RESULTS AND DISCUSSION}

The stem and leaf explants were inoculated in B5 media augmented with different combination and composition of BAP, kn NAA and 2, 4-D. The results have been presented in (Table 1) and Figure 1).After one week of inoculation callusesturned up reddish due to secretions of secondarymetabolites.It was observed that B5 media augmented with BAP concentration ranges from 0.1 to $2.5 \mathrm{mg} / \mathrm{l}$ and NAA ranges $0.1-0.5 \mathrm{mg} / \mathrm{l}$ lead to formation of callus from leaf and stem explants (Figure 1). The calli obtained from the leaf were green, brown, compact and friable in nature.The same type of calli was also obtained from stem explants in B5 media fortified with BAP 0.1-2.5 mg/l and NAA 0.1-0.5 mg/l.Higher concentration of plant growth regulators leads to formation of brown and friable calli (Tables 1 and Figure 1-g,i) while lower concentration of plant growth regulators induced compact and green calluses (Tablesland Figure j).Lower concentration of BAP and NAA induced green and compact calli in both stem and leaf whereashigher concentration was responsible for brown and friable callus. Leaf and stem explants showed callus induction after one week of inoculation. BAP $0.1 \mathrm{mg} / \mathrm{l}$ and NAA0.1 mg/l induced callus formation after 12 days in leaf explants and 13 days in stem explants after inoculation. BAP $2.5 \mathrm{mg} / \mathrm{l}$ and NAA 0.5 $\mathrm{mg} / \mathrm{l}$ lead to formation of callus after 07 days in leaf and 09 days in stem explants.B5 media supplemented with $\mathrm{Kn}$ and 2, 4-D formed brown, compact and friable calluses (Tablesl). Keeping the concentration of 2, 4-D constant and increasing the concentration of $\mathrm{kn}$ from 1 to $4 \mathrm{mg} /$ (Figure g) leads to formation of brown and friable callus whereas in 1 and $2 \mathrm{mg} / \mathrm{l}$ of $\mathrm{kn}$ induced compact and brown callus in both and stem and leafexplants. Friability increases after increasing the concentration of plant growth regulators. Minimum calluses responses was observed after one week of inoculation (Table 1) while maximum duration 
was seventeen days for induction (Table 1) of callus responses in the stem explants. BAP $2.5 \mathrm{mg} / \mathrm{l}$ augmented with NAA 0.5 $\mathrm{mg} / \mathrm{l}$ showed 10 out of 10 culture vessels in both explants, whereas kn $2 \mathrm{mg} / \mathrm{l}$ supplemented with $0.2 \mathrm{mg} / \mathrm{l}$ 2, 4-D results 8 out of ten culture vessels in stem and leaf explants. BAP showed
$100 \%$ calluses response and $\mathrm{Kn}$ showed $80 \%$ response.The moisture content of calluses obtained from both the explants was determined by drying the calluses in incubator (Table 2). The leaf explants showed minimum moisture content $59 \%$ and maximum $91 \%$ while in stem minimum moisture content
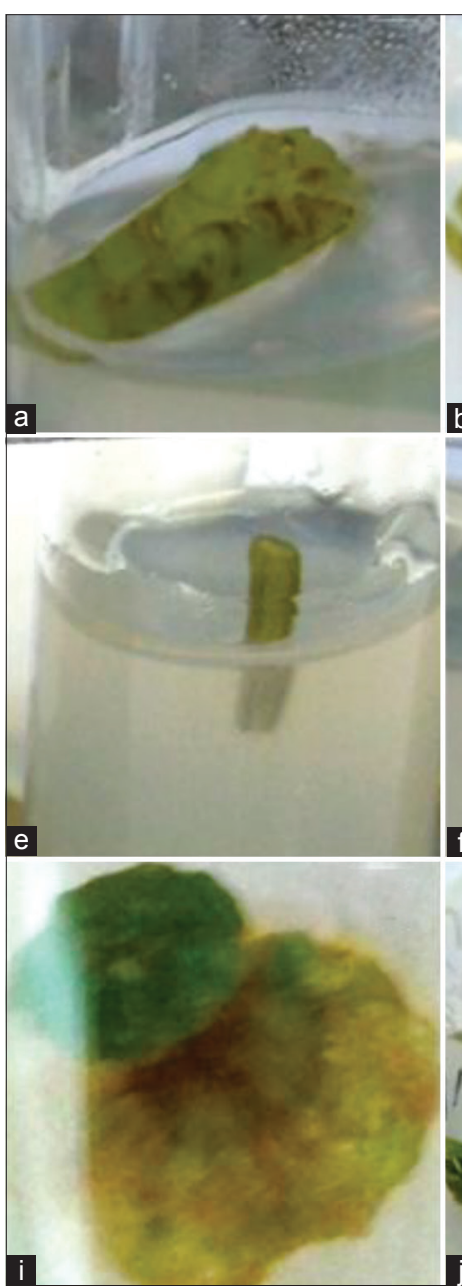
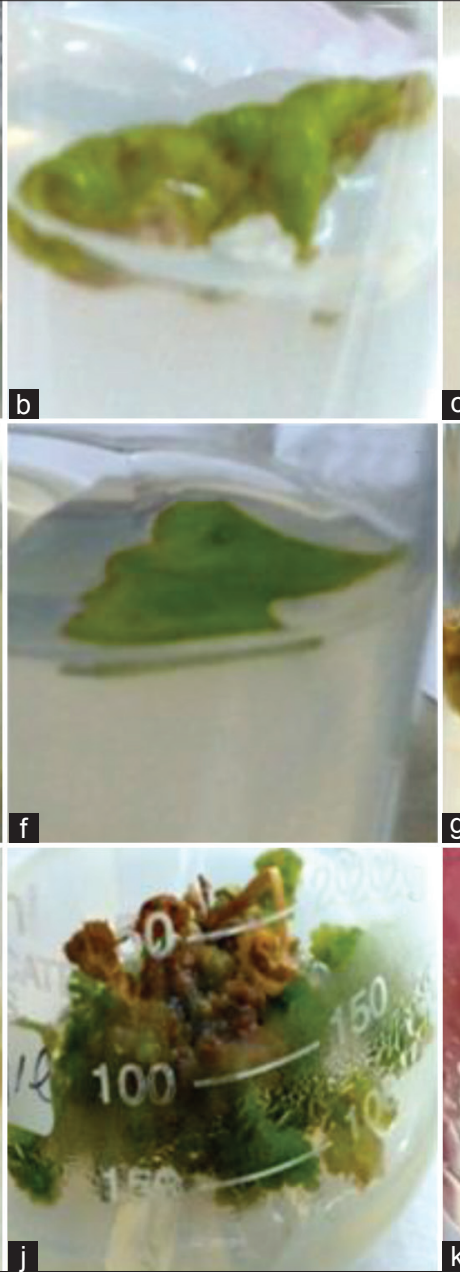

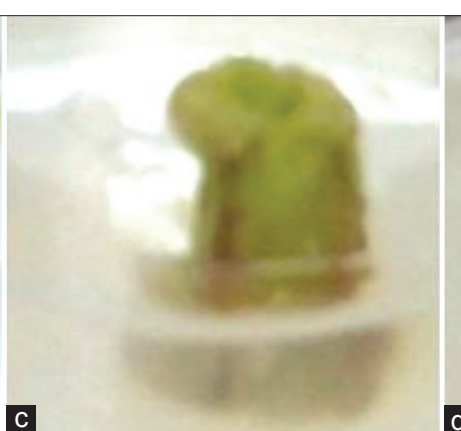

d
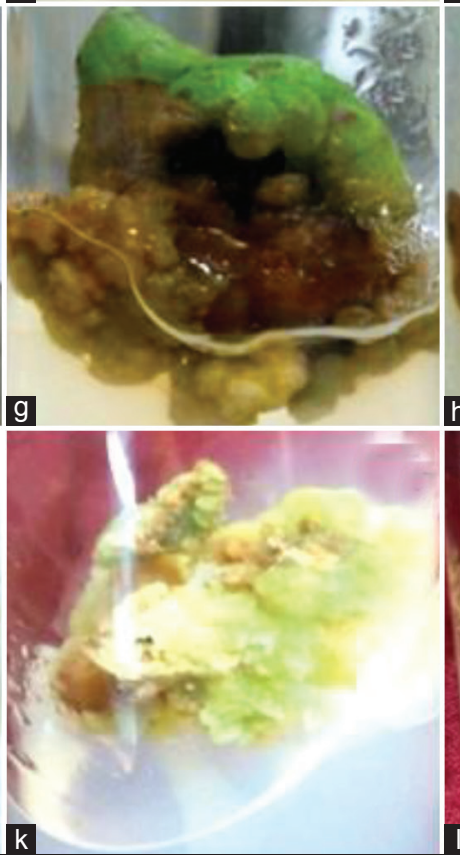

h
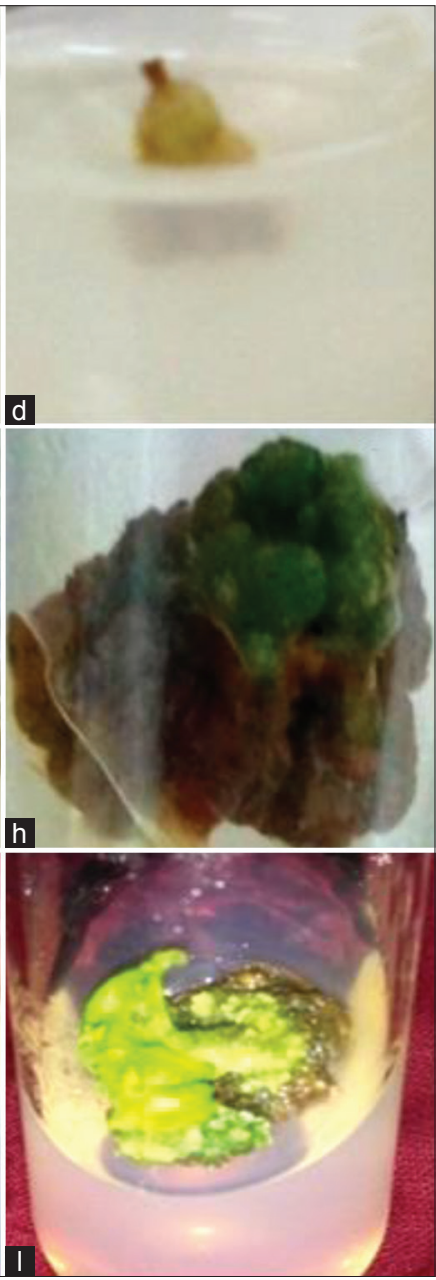

Figure 1: (a-l) different stage ofcallus induction in B5 media(a), (b), (c) Leaf explants after one week of inoculation, (d), (e), (f) Stem explants after one week of inoculation. (g), brown and friable callus $\mathrm{kn} 4 \mathrm{mgl} / \mathrm{l}$ and 2,4-D 0.2 mg/l. (h), (j) green and compact calli BAP $2 \mathrm{mg} / \mathrm{l}$ and NAA $0.5 \mathrm{mg} / \mathrm{l}$. (i) brown and compact calli $\mathrm{kn} 1 \mathrm{mg} / \mathrm{l}$ and $0.2 \mathrm{mg} / \mathrm{l}$. (k) 6 week old callus of leaf explants. (l) green callus of leaf.

Table 1: Callus induction in leaf and stem explants in B5 media supplemented with BAP (0.1-2.5 mg/l) and NAA (0.1- $0.5 \mathrm{mg} / \mathrm{l})$, $\mathrm{Kn}(1-4 \mathrm{mg} / \mathrm{l})$ and $2,4-\mathrm{D}(0.2 \mathrm{mg} / \mathrm{l})$

\begin{tabular}{|c|c|c|c|c|c|c|c|}
\hline \multicolumn{4}{|c|}{ Growth regulators } & \multicolumn{2}{|l|}{ Leaf } & \multicolumn{2}{|l|}{ Stem } \\
\hline BAP & NAA & $\mathrm{Kn}$ & 2,4-D & Type of callus & Day of callus induction & Type of callus & Day of callus induction \\
\hline 0.1 & 0.1 & 0 & 0 & Green compact & 12 & Green compact & 13 \\
\hline 0.2 & 0.1 & 0 & 0 & Green compact & 11 & Green compact & 12 \\
\hline 0.3 & 0.1 & 0 & 0 & Brown compact & 08 & Green compact & 11 \\
\hline 0.4 & 0.2 & 0 & 0 & Green friable & 09 & Brown compact & 10 \\
\hline 0.5 & 0.2 & 0 & 0 & Brown friable & 08 & Brown compact & 09 \\
\hline 1 & 0.2 & 0 & 0 & Brown friable & 07 & Brown compact & 08 \\
\hline 2 & 0.5 & 0 & 0 & Green friable & 13 & Green friable & 07 \\
\hline 2.5 & 0.5 & 0 & 0 & Green friable & 07 & Brown compact & 07 \\
\hline 0 & 0 & 0.2 & 1 & Brown compact & 08 & Brown compact & 08 \\
\hline 0 & 0 & 0.2 & 1.5 & Brown compact & 11 & Brown compact & 10 \\
\hline 0 & 0 & 0.2 & 2 & Brown compact & 09 & Brown compact & 14 \\
\hline 0 & 0 & 0.2 & 2.5 & Brown compact & 13 & Brown friable & 10 \\
\hline 0 & 0 & 0.2 & 3 & Brown friable & 17 & Brown friable & 11 \\
\hline 0 & 0 & 0.2 & 4 & Brown friable & 15 & Brown friable & 09 \\
\hline
\end{tabular}


was $60 \%$ and maximum $95 \%$. The minimum fresh weight was $(0.27 \mathrm{mg})$ and dry weight $(0.03 \mathrm{mg})$ for leaf and maximum fresh and dry weight of leaf explants were $(0.27 \mathrm{mg})$ and $(0.03$ $\mathrm{mg})$ respectively. The minimum fresh and dry weight was(1.06 $\mathrm{mg})$ and $(0.16 \mathrm{mg})$ for explants and maximum fresh and dry weight $(3.78 \mathrm{mg})$ and $(0.42 \mathrm{mg})$ respectively.BAP has been better plant growth regulators as compared to kn and showed better growth. Stem explants were better explants over leaf explants for callus induction. No callus responses were obtained without plant growth regulators.

Effect of different combinaton and composition of BAP and NAA, Kn and 2,4- D on callus induction and type of callus on leaf and stem explants.

\section{Multiplication of Shoots}

Calluses derived from stem and leaf explants were further inoculated in shooting media.BAP $(0.5-1.5 \mathrm{mg} / \mathrm{l})$ fortified with NAA $(0.1-0.5 \mathrm{mg} / \mathrm{l})$ in B5 media leads to formation of shoots in Centella asiatica. BAP $1.5 \mathrm{mg} / \mathrm{l}$ and NAA $0.5 \mathrm{mg} / \mathrm{l}$ has maximum shoot length $2.01 \mathrm{~cm}$ whereas BAP $01 \mathrm{mg} / \mathrm{l}$ and NAA $0.2 \mathrm{mg} / \mathrm{l}$ have minimum shoot length of $0.49 \mathrm{~cm}$. Number of shoots per explants was minimum at BAP $(01 \mathrm{mg} / \mathrm{l})$ and $\mathrm{NAA}(0.2 \mathrm{mg} / \mathrm{l})$ while maximum at BAP (1.5 mg/l) and NAA (0.5 mg/l) (Table3 Figure 2).It has been observed that low concentration of plant growth regulators showed poor growth and high concentration showed green shoots with branching. After transfer of callus in shooting media shoots were regenerated after four week of inoculation.

\section{Root Induction}

After shooting, 1.5 -2 cm long shoots were transferred in full strength B5media augmented with BAP $0.1 \mathrm{mg} / \mathrm{l}$ and NAA
0.1-0.5 forroot induction. The results have been presented in (Table 4 and Figure 3). It has been shown that $0.1 \mathrm{mg} / \mathrm{l} \mathrm{BAP}$ fortified with NAA $0.5 \mathrm{mg} / \mathrm{l}$ showed $100 \%$ rooting, highest root per shoot $11.6 \mathrm{~cm}$ and mean root length $1.86 \mathrm{~cm}$. However percentage of rooting, root length and number of roots per shoot varied among the different media composition. It has been observed that increasingthe concentration of NAA enhances the percentage rooting, number of roots per shoot as well as root length. No resultsof rooting were observed in BAP augmented with IBA.

\section{Acclimatization of Plantlets}

For acclimatization well developed plantlets were isolated from rooting media and washed with luke warm double distilled water for removal of agar and subjected to hardening. Plantlets were transferred in soil mixture containing vermiculatie sand and soil (1:1:1) in plant growth chambers for 2 week (Figure 4). The plantlets were transferred into earthen pots into green house, potted in 3; 1 vermicompost and soil for another 2 week. After then plants were kept outside under full sunlight which is resulted into $90 \%$ survival.

\section{Analysis of Phenol}

Subsequent analysis of total phenolic content was determined In vivo leaf, stem and invitrogrown 40 days old leaf and stem calluses. The percentage yield of total ethanolic alkaloid contents were $11.8 \%, 12 \%$ and $21 \%$ in powder tissues of stem, leaf and invitro raised calluses respectively. Calluses contain more alkaloid contents as compared to the explants. The phenoliccontent of calluses was more as compared to leaf and stem explants. The callus contained $0.67 \mathrm{mg} / \mathrm{gm} \mathrm{dw}$ of phenolic while leaf $0.63 \mathrm{mg} / \mathrm{gmdw}$ and stem $0.59 \mathrm{mg} / \mathrm{gmdw}$ respectively.

Table 2: Growth of leaf and stem calluses were observed by measuring callus fresh weight and dry weight in (gm) from randomly selected samples of different concentration and combination of plant growth regulators

\begin{tabular}{|c|c|c|c|c|c|c|}
\hline \multirow[t]{2}{*}{ B5 media with PGR ( $\mathrm{mg} / \mathrm{l})$} & \multicolumn{3}{|c|}{ Leaf } & \multicolumn{3}{|c|}{ Stem } \\
\hline & Fresh Weight (gm) & Dry weight (gm) & $\%$ moisture content & Fresh Weight (gm) & Dry weight (gm) & $\%$ moisture content \\
\hline $\operatorname{BAP}(0.2)+N A A(0.2)$ & 0.27 & 0.11 & 59 & 3.09 & 0.18 & 94 \\
\hline $\operatorname{BAP}(0.4)+N A A(0.2)$ & 0.33 & 0.06 & 81 & 3.37 & 0.24 & 92 \\
\hline $\mathrm{BAP}(01)+\mathrm{NAA}(0.2)$ & 0.68 & 0.09 & 86 & 3.78 & 0.23 & 93 \\
\hline $\operatorname{BAP}(2.5)+N A A(0.5)$ & 0.35 & 0.03 & 91 & 3.25 & 0.16 & 95 \\
\hline $\mathrm{Kn}(1)+2,4-\mathrm{D}(0.2)$ & 1.51 & 0.17 & 88 & 2.13 & 0.31 & 85 \\
\hline $\mathrm{Kn}(2)+2,4-\mathrm{D}(0.2)$ & 2.36 & 0.27 & 88 & 1.74 & 0.16 & 90 \\
\hline $\mathrm{Kn}(2.5)+2,4-\mathrm{D}(0.2)$ & 1.47 & 0.24 & 86 & 1.96 & 0.38 & 80 \\
\hline $\mathrm{Kn}(4)+2,4-\mathrm{D}(0.2)$ & 1.76 & 0.37 & 78 & 1.06 & 0.42 & 60 \\
\hline
\end{tabular}

Table 3: Shooting B5 media augmented with combination of BAP $(0.5-1.5 \mathrm{mg} / \mathrm{l})$ and NAA $(0.1 \mathrm{mg} / \mathrm{l})$

\begin{tabular}{|c|c|c|c|c|c|}
\hline $\mathrm{BAP}(\mathrm{mg} / \mathrm{l})$ & $\mathrm{NAA}(\mathrm{mg} / \mathrm{l})$ & Shooting Percentage & Shoot length $(\mathrm{cm})$ & No. of shoots per explants & Remarks \\
\hline 0.5 & 0.1 & 41 & $1.05 \pm 0.12$ & $1.38 \pm 0.12$ & Poor growth \\
\hline 0.5 & 0.1 & 28 & $0.95 \pm 0.07$ & $1.62 \pm 0.16$ & Poor growth \\
\hline 01 & 0.2 & 31 & $0.49 \pm 0.22$ & $0.80 \pm 0.13$ & Green shoots \\
\hline 01 & 0.2 & 43 & $1.15 \pm 0.25$ & $1.46 \pm 0.17$ & Green shoots \\
\hline 1.5 & 0.5 & 29 & $0.15 \pm 0.14$ & $1.45 \pm 0.17$ & Green shoots with branching \\
\hline 1.5 & 0.5 & 67 & $2.01 \pm 0.10$ & $2.25 \pm 0.32$ & Green shoots with Branching \\
\hline
\end{tabular}

Means were represented as means \pm SE (10 explants per culture vessels repeated three times) 
Table 4 :Rooting B5 media fortified with BAP $(0.1 \mathrm{mg} / \mathrm{l})$ and NAA $(0.1 \mathrm{mg} / \mathrm{l})$

\begin{tabular}{lccc}
\hline BAP $(\mathrm{mg} / \mathrm{l})$ & NAA $(\mathrm{mg} / \mathrm{l})$ & Rooting \% & No. of roots/per shoot \\
\hline 0.1 & 0.1 & $17 \pm 1.5$ & $8.125 \pm 1.36$ \\
0.1 & 0.2 & $28 \pm 2.25$ & $10.28 \pm 1.45$ \\
0.1 & 0.3 & $30 \pm 3.5$ & $7.21 \pm 1.03$ \\
0.1 & 0.4 & $36 \pm 4.5$ & $5.05 \pm 0.86$ \\
0.1 & 0.5 & $100 \pm 07$ & $11.56 \pm 1.64$ \\
0.1 & 0.6 & $80 \pm 6.5$ & $6.08 \pm 0.96$
\end{tabular}

Means were represented as means \pm SE (10 explants per culture vessels repeated three times)

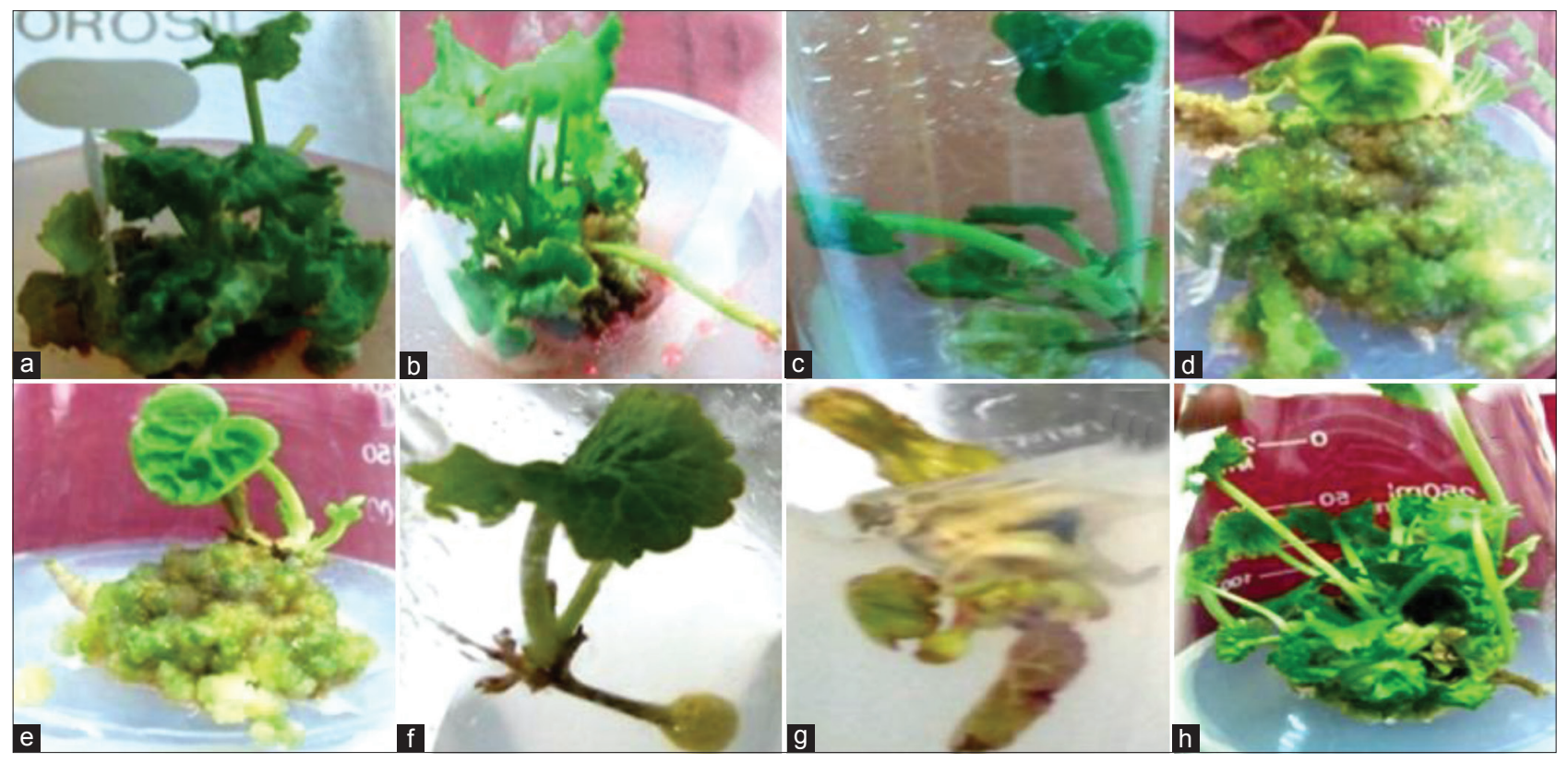

Figure 2: (a-h) Different stages of indirect regeneration in Centella asiatica

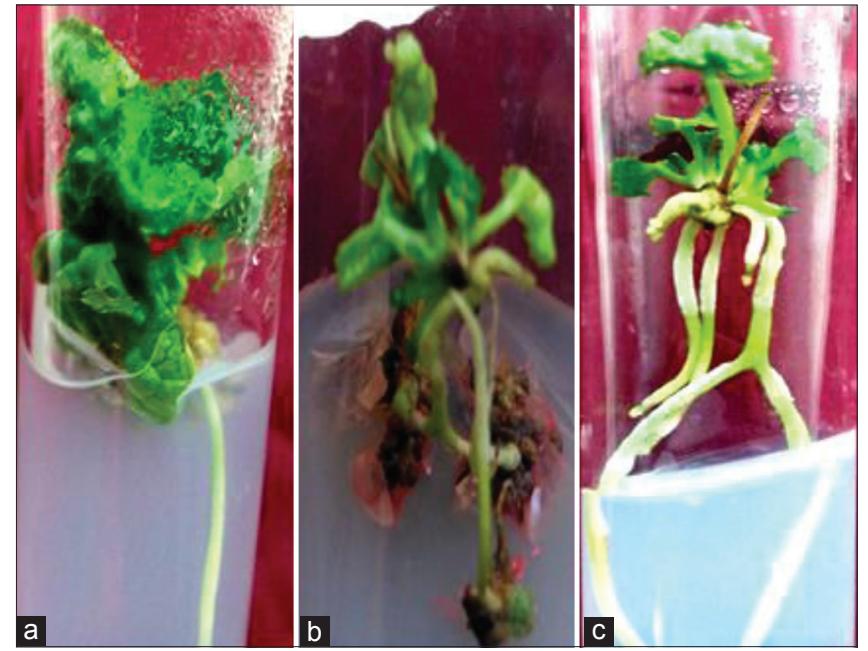

Figure 3: (a-c) Different types of roots developed in B5 media

\section{DISCUSSION}

Micropropagation protocol represents minimum coast techniques, by which we can obtained high quantity of plants. In micropropagation by using phytohormones reduced expenses and enhances fast and effective plant production. The present investigation standardized a protocol for callus induction and regeneration from stem and leaf explants in Centella asiatica. This experiment determined a protocol for shoot proliferation and root emergence from the callus. The combination of BAP and NAA was essential for callusinduction as well as plant regeneration[2, 18-26]. The effectiveness BAP and NAA showed by various researchers in Centella asiatica [30]. BAP and Kn showed significant role in callus induction [21].Combination of Kn with 2, 4-D showed good results which is same as previous findings $[27,28]$. But the characteristics feature of callus was different. The culture condition, age and type of explants may attribute for this differences. The combination of cytokinin and auxin are very important for callus induction and multiplication of shoots from the explants. No regeneration was observed without the growth regulators [18]. Similar regeneration was reported in combination of BAP and NAA in B5 media [15, 24].Phenols are the important constituents of the medicinal plants possess hydroxyl groups which are mainly responsible for antioxidant property in any plants. Various researches have been conducted on polyphenols and stated that polyphenols showed inhibitory effect against cancer and mutation. The callus contains more amounts of phenolics as compared to explants and leaf has also high amount of phenolic as compared to stems. Callus cultures have ability to attain significant amounts of phenolics compound as compared to the counter parts of In vivo grown plants. Callus grow in nutrient rich media, which is exposed to more carbon 

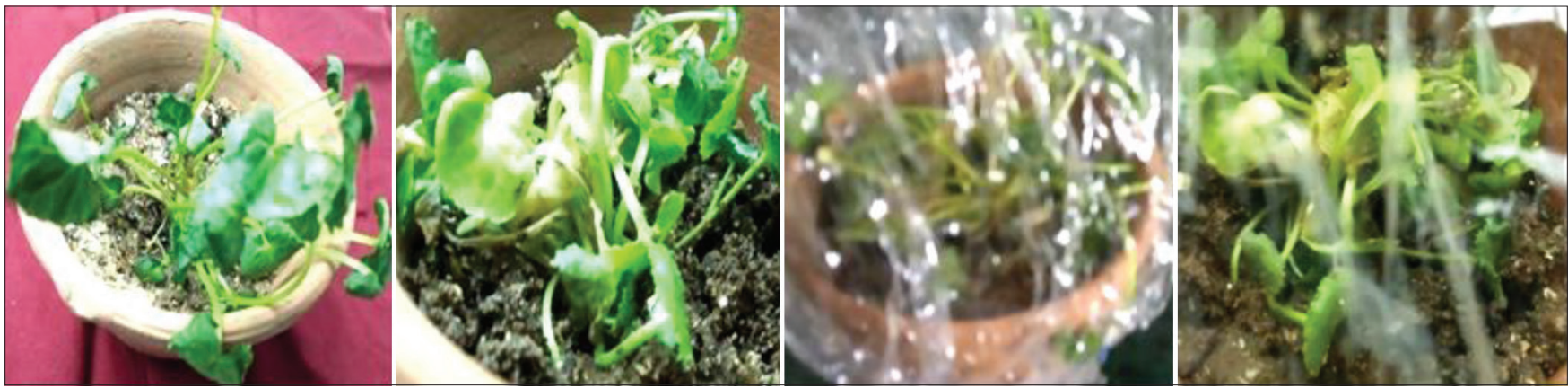

Figure 4: In vitro regenerated plantlets in B5 media of Centella asiatica

influx than the In vivo grown, it might attribute to influence metabolic flux for the synthesis of increased level of phenolics. Phenolics compounds have redox properties which are also responsible for antioxidant properties. Among the three plant parts (leaf, stem, and callus) of Centella asiatica, the callus showed maximum amounts of total phenolics compound. Plant tissue culture techniques are very important tools for secondary metabolites production. Callus culture has been mostly used for secondary metabolites production against the intact plants. Several researchers have been reported secondary metabolite production through the in vitro culture in various medicinal plants [31-33].

\section{CONCLUSION}

The callus induction and regeneration of plantlets were easily maintained in B5 media fortified with auxin Viz: NAA, 2, 4-D and cytokinin BAP and NAA. The experiment revealed that combination and composition of plant growth regulators are responsible for callus induction as well as regeneration of plantlets. Combination of BAP and NAA are the best for callus induction over the combination of $\mathrm{Kn}$ and 2, 4-D. For callus induction stem is better explants as compared to leaf explants, however leaf contains high amount of phenolics relative to stem. Callusesshowed more amounts of phenolicsas compared to both the explants. Higher of plant growth regulators enhances callus induction as well as shoot multiplication and root induction. B5 medium augmented with BAP and NAA are responsible for shooting and rooting. Rooted plantlets were transferred into field where they achieved $90 \%$ establishment successfully. The investigation may be concluded that a simple and efficient protocol was developed for rapid callus induction and regeneration in C. asiatica. The determination of phenolics suggested that the callus possessed high amounts of metabolites as compared to explants. This micropropagatedprotocol might be helpful in conservation of $C$. asiatica which is under threatened species due to overexploitation.

\section{ACKNOWLEDGEMENT}

We express grateful thanks to Department of Biotechnology government of India for financial assistanship and Dr. Chandra Prabha, P. G Department of Botany, P.U Patna.

\section{REFERENCES}

1. Narula A, Kumar S, Bansal K, Srivastava PBiotechnological approaches towards improvement of medicinal plants. In: Srivastava P, Narula A, Srivastava S. (eds) Plant biotechnology and molecular markers: Springer Dordrecht; 2004.

2. Rao S, Usha K, Arjun. Production of secondary metabolites from callus cultures of Centella asiatica (L.) Urban. Annals of Phytomedicine. 2015; 4: 74-78.

3. James JT, Dubery IA. Pentacyclic triterpenoids from the medicinal herb,Centellaasiatica (L.) Urban. 2009;14: 3922-394.

4. Govarthanan M, Rajinikanth R, KannanSK, SelvankumarT. A comparative study on bioactive constituents between wild and in vitro propagated Centella asiatica. Journal of Genetic Engineering and Biotechnology. 2015; 13: 25-29.

5. Gandi S, Giri A. Production and quantification of asiatic acid from in vitro raised shoots and callus cultures of Centella asiatica (L.) Urban. Annals of Phytomedicine. 2013; 2: 95-101.

6. Somboonwong J, Kainkaisre M, Tantisira B, Tantisira MH. Wound healing activities of different extracts of Centella asiatica incision and burn wound models: an experimental animal study. BMC complementary and alternative medicine. 2012; 12: 103.

7. Mahapatra KD, Kumar B. Ancient and pharmacological review on Centella asiatica (Mandukparni): A potential herbal panacea. International journal of research and reviews in pharmacy and applied science. 2012;6: 1062-1072.

8. Lucia R D C, Sertic JAA, Camargo E A, Panizza S.Pharmacological and Toxicological Studies in Centella Asiatica Extract. Fitoterapia. 1997; LXVIII: 413-416.

9. Minija J,Thoppil JE. Antimicrobial Activity of Centella Asiatica L. Urb. Essential oil. Indian Perfumer. 2003; 47: 179-181

10. Mamtha B, Kavitha K, Srinivasan KK, Shivnanda PG. An In Vitro Study of the Effect of Centella asiatica (Indian Pennywort) on Enteric Pathogens. Ind. J. Pharmocol. 2004; 36: 41-44.

11. Marquart FX, Bellon G, Gillery P, Wegrowski Y. Triterpenes from Centella asiatica Stimulate Extracellular Matrix Accumulation in Rat Experimental Wounds. Euro. J. Dermat. 1999;9:289.

12. Allegra C.Comparative Capillaroscopic study of certain bioflavonoids and total triterpenic fractions of Centella asiatica in venous insufficiency.Clin Ther.1981; 99:507-13.

13. Chen $Y$, Han T, Qin L, Rui Y, Zheng H. Effect of total triterpenes from Centella asiatica on the depression behaviour and concentration of amino acid in forced swimming mice. Zhong Yao Cai. 2003;26:870-3.

14. Hausen BM. Centella asiatica (Indian pennywort) an effective therapeutic but a weak sensitizer. Contact Dermatitis. 1993; 29:175-9.

15. Kim OT, Kim MY, Huh SM,Ahn JC, Seong NS, Hwang B. Effect of growth regulators on asiaticoside production in whole plant cultures of Centella asiatica (L.) Urban. Journal of Plant Biology. 2004; 47:361-365.

16. Patra A, Rai B, Rout GR, Das P. Succesful plant regeneration from callus cultures of Centella asiatica (Linn.) Urban. Plant Growth Regulation. 1998; 24: 13-16.

17. Gamborg OL, Miller RA, Ojima K. Plant tissue culture methods. Exp. cell. Res. 1968; 50: 151-158.

18. Mohapatra H, Barik DP, Rath SP. In vitro regeneration of medicinal plant Centella asiatica. Biologia Plantarum. 2008; 52:349-342.

19. Kumar MS. Rapid in Vitro multiplication of Centella asiatica (L). Urban. 
Through multiple shoots from leaf explants. European Journal of Biotechnology and Bioscience. 2017; 5: 41-47.

20. Panathula CS, Mahadev MD, Naidu CV. High efficiency adve.ntitious indirect organogenesis and plant regeneration from callus of Centella asiatica (L.)- An important antijaundice medicinal plant. International Journal of Advanced Research. 2014; 2: 1027-1036.

21. Naidu TB, Rao SN, Mani NS, Mohan YSYVJ, Pola, S. Conservation of an endangered medicinal plant Centella asiatica through plant tissue culture. Drug Invention Today. 2010; 2: 17-21.

22. Das R, Hasan MF, Hossain MS, Rahman M. Micropropagation of Centella asiatica L. an important medicinal herb. Progress. Agric. 2008; 19: 51-56

23. Bibi Y, Zia M, Nisa S, Habib D, Waheed A, Chaudhary FM. Regeneration of Centella asiatica plants from non-embryogeneic cell lines and evalution of antibacterial and antifungal properties of regenerated calli and plants. Journal of Biological Engineering. 2011:5: 13.

24. Roy A, Kundu K, Saxena G, Kumar L, Bharadvaja N. Effect of different media and growth hormones on shoot multiplication of in vitro grown Centella asiatica accession. Advanced Techniques in Biology \& Medicine. 2016; 4: 2 .

25. Joshi K, Chaturvedi P, Subhpriya. Efficient in vitro regeneration protocol of Centella asiatica (L.): An endemic underutilized nutraceutical herb. African journal of Biotechnology. 2013; 12: 5164-5172.

26. Nath S, Buragohain AK. In vitro method for propagation of
Centella asiatica (L) Urban by shoot tip culture. J. Plant Biochemistry \& Biotechnology. 2003; 12: 167-169.

27. Tan SH, Musa R, Ariff A, Maziah M. Effect of plant growth regulators on callus, cell suspension and cell line selection for flavonoid production from Pegaga (Centella asiatica L. Urban). American Journal of Biochemistry and Biotechnology. 2010; 6: 284-299.

28. Tiwari KN, Sharma NC, Tiwari V, Singh BD. Micropropagation of Centella asiatica (L.) a valuable medicinal herb. Plant Cell, Tissue and Organ Culture. 2000; 63: 179-185.

29. Cai T, Daly B, Butler L. Callus induction and plant regeneration from shoot portions of mature embryos of high tannin sorghum. Plant cell, Tissue and Organ Culture. 1987; 9: 242-252.

30. Ritika K, Ali AS, Anjali S. Micropropagation of Centella asiatica through tissue culture an attempt to develop an efficient protocol for large scale production. Indian Journal of Scientific Research. 2018; 8:41-45.

31. Song K, Kumar P, Arivazhagan G, Lee SI, Yoon HM, Kim IH, Kim HJKJM, Hakkim FL. Antioxidant propert of leaves and calluses extracts of in-vitro grown 5 different Ocimum species. 2012; 39: 146-153.

32. Baba SA, Malik SA. Determination of total phenolic and flavonoid content, antimicrobial and antioxidant activity of a root Extract of Arisaema Jacquemontii Blume. 2015; 9: 449-454.

33. Kumar MS, Chaudhury S, Balachandran S. In vitro callus culture of Heliotropium indicum Linn. For assessment of total phenolic and flavonoid content and antioxidant activity. 2014; 174: 2897-2909. 